\title{
(S)SAGE
}

\section{American Academy of Political and Social Science}

\section{Mediating Regional Conflicts and Negotiating Flexibility: Peace Efforts in Bosnia-}

\section{Herzegovina}

Author(s): Nimet Beriker Atiyas

Source: The Annals of the American Academy of Political and Social Science, Vol. 542, Flexibility in International Negotiation and Mediation (Nov., 1995), pp. 185-201 Published by: Sage Publications, Inc. in association with the American Academy of Political and Social Science

Stable URL: https://www.jstor.org/stable/1048216

Accessed: 29-01-2019 12:51 UTC

JSTOR is a not-for-profit service that helps scholars, researchers, and students discover, use, and build upon a wide range of content in a trusted digital archive. We use information technology and tools to increase productivity and facilitate new forms of scholarship. For more information about JSTOR, please contact support@jstor.org.

Your use of the JSTOR archive indicates your acceptance of the Terms \& Conditions of Use, available at https://about.jstor.org/terms

Sage Publications, Inc., American Academy of Political and Social Science are collaborating with JSTOR to digitize, preserve and extend access to The Annals of the American Academy of Political and Social Science 


\title{
Mediating Regional Conflicts and Negotiating Flexibility: Peace Efforts in Bosnia-Herzegovina
}

\author{
By NIMET BERIKER ATIYAS
}

\begin{abstract}
This study analyzes four mediation initiatives in the conflict in Bosnia-Herzegovina in order to understand the differences between mediators' capabilities and their effect on the negotiating flexibility of the disputing parties. It is claimed that regardless of the outcomes of the negotiations, in all mediation cases, parties adopted flexible negotiating behavior in the form of making or offering concessions, agreements on rules and procedures, agreements on mutual solutions, and introducing new peace proposals. In all instances, the mediators played both the facilitator and manipulator roles. The difference between a mediation process leading to an agreement and one ending with a stalemate is found in the way and extent to which a mediator uses his or her leverage in playing the role of a manipulator.
\end{abstract}

Nimet Beriker Atiyas is an assistant professor in the Department of International Relations of Bilkent University, in Ankara, Turkey. Beriker Atiyas has a continuing interest in the process of international negotiation and mediation. Power symmetry and asymmetry in negotiations, conflict escalation and de-escalation in intercommunal disputes, and the use of content analysis in negotiation research are specific topics that she is currently studying and writing about. 
$\mathrm{C}^{\mathrm{ROM}}$ February 1992 onward, four

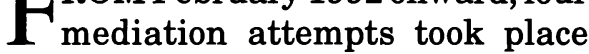
with the aim of ending the conflict between the Bosnian Serbs, Croats, and Muslims: (1) the European Community (EC)/Conference on Security and Cooperation in Europe (CSCE) mediation by Jose Cutiliero and Lord Carrington (February-August 1992); (2) the U.N./EC mediation by Cyrus Vance and Lord Owen (September 1992-June 1993) and by Thorvald Stoltenberg and Lord Owen (JulyDecember 1993); (3) the U.S. mediation by Charles Redman (JanuaryApril 1994); and (4) the Contact Group mediation, by the United Nations, the European Union (EU), the United States, and Russia (April 1994). Of these interventions, only one attempt, that of the United States, generated a lasting agreement between two warring factions, the Bosnian Croats and Muslims. The parties agreed on the establishment of a federation between the Bosnian Croats and Muslims and a loose confederation between this federation and Croatia.

This article concerns the U.S. and other mediation efforts in BosniaHerzegovina. It analyzes the U.S. mediation effort together with other mediation attempts-the EC/CSCE and the U.N./EC mediations-to understand differences in the capabilities of the respective mediators and their effect on the negotiating flexibility of conflicting parties. The Contact Group mediation effort, by the United Nations, EU, United States, and Russia, is not a subject of this study since it is still in progress. The separation of third party efforts into four exercises by different intermediaries serves as an analytical device to answer questions concerning how third parties contribute to negotiating flexibility. It does not necessarily reflect the conflicting parties' perception of the events.

The article first examines the roles of the mediators in their search for agreement between parties. A description of the roles of the mediators is followed by an analysis of the negotiation processes. The purpose of this second section is to show that the way and extent to which the mediator uses his or her leverage in playing the role of a manipulator affects the negotiations. In other words, this section indicates, first, that mediators who practice manipulative tactics during the negotiations produce flexibility in negotiation, while mediators who manipulate the conflict environment before the negotiations produce both flexibility and sustainable agreements.

Second, it indicates that mediators who have high capability to manipulate the conflict environment produce both flexibility and a sustainable agreement but that mediators whose manipulative capabilities are low are limited to producing flexibility but fail to produce agreements. The database for the analysis consists of printed and broadcast news (Foreign Broadcast Information Service, Keesing's, Radio Free Europe, BBC World Reports, newspapers) starting in March 1992, the starting date of the conflict in Bosnia-Herzegovina.

\section{NEGOTIATING FLEXIBILITY}

In this study, negotiating flexibility is defined as any action taken to facilitate a movement in the direction 
of a mutually acceptable agreement. Among other things, this may take the form of withdrawing support from an already stated position that complicates achievement of an agreement, or of introducing to the negotiating situation new resources that increase complementary interests and thereby enable creative outcomes.

The foregoing definition encompasses two different negotiating situations: positional bargaining negotiation and problem-solving negotiation. Positional bargaining structurally comprises target and resistance points and bargaining ranges. ${ }^{1}$ In this negotiation situation, the aim of the parties is to increase their own gain while preventing the other party from doing the same. Therefore, in positional bargaining, flexibility may be defined in terms of the changes in the position of a party (in the direction of the other party's preferred position) relative to his or her own and the other party's target and resistance points. $^{2}$ In this context, concession making or reaching agreements on procedures may constitute examples of negotiating flexibility.

In the second negotiating situation, problem-solving negotiation, parties perceive the complementary nature of the relationship and try to maximize their mutual gains by cooperating. ${ }^{3}$ In this negotiation situ-

1. Richard E. Walton and Robert B. McKersie, A Behavioral Theory of Labor Negotiations: An Analysis of a Social Interaction System (New York: McGraw-Hill, 1965).

2. See Daniel Druckman, "Situational Levers of Position Change: Further Explorations," this issue of The Annals of the American Academy of Political and Social Science.

3. Walton and McKersie, Behavioral Theory of Labor Negotiations. ation, strategies such as creating viable options or agreeing on a mutual solution may be considered as attributes of flexible behavior. Consequently, in this framework, flexibility may be considered to be equivalent to cooperative negotiation behavior.

The intellectual task, then, requires drawing the conceptual line between concession making and cooperative negotiation behavior, on the one hand, and negotiating flexibility, on the other. Taking a third negotiating situation as an analytical unit can help to conceptualize negotiating flexibility. Treating negotiation as a hybrid process, involving the attributes of both positional and problem-solving negotiating situations, allows one to understand the difference between negotiating flexibility, on the one hand, and the concessionmaking processes of positional bargaining, and the cooperative behavior of problem-solving negotiations, on the other. In this hybrid framework, flexibility encompasses both concession-making strategies and cooperative behavior-such as creating viable solutions or agreeing on a mutual solution-but is not equivalent to them. All efforts to convert positional bargaining into problem-solving negotiations are also viewed as elements of negotiating flexibility. Issue reframing, acknowledgment of others' feelings, synchronized de-escalation, establishing commonalities, and agreeing on rules and procedures may be examples of activities that can convert positional bargaining into problem-solving negotiations. Therefore, I regard negotiating flexibility as a process consisting of the conciliatory elements of positional bargain- 
ing together with the cooperative elements of problem-solving negotiations as well as activities and efforts that attempt to convert positional bargaining to problem solving.

This broad definition of negotiating flexibility is not, however, equivalent to the negotiation process itself. The latter, in addition to the elements already mentioned, also encompasses competitive negotiation behavior, such as threats, commitments, and bluffs.

\section{MEDIATION AND NEGOTIATING FLEXIBILITY}

For many researchers, ${ }^{4}$ mediation is an extension of the negotiation process, being the transformation of a dyadic negotiating interaction into a triangle. ${ }^{5}$ In mediation literature, the relationship between the mediator and the flexibility of the negotiating parties has been elaborated on by focusing on the different aspects of the functions of the mediator. Some themes used to express the connection between the mediator's role and the flexibility of the parties are the following: "[assisting] the graceful retreat," "[inducing] the parties to

4. C. Kerr, "Industrial Conflict and Its Mediation," American Journal of Sociology, 60:230-45 (1954); Christopher W. Moore, The Mediation Process: Practical Strategies for Resolving Conflict (San Francisco: Jossey-Bass, 1986); John Burton, Conflict and Communication: The Use of Controlled Communication in International Relations (London: Macmillan, 1969); Peter J. Carnevale and Dean G. Pruitt, "Negotiation and Mediation," Annual Review of Psychology, 43:531-82 (1992).

5. M. Barkun, cited in C. R. Mitchell, The Structure of International Conflict (New York: St. Martin's Press, 1981).

6. Kerr, "Industrial Conflict and Its Mediation," pp. 230-45. make concessions and accept compromised proposals," "[helping] return negotiations to a productive pace," "creating pressure toward agreement," "facilitating concession making and problem solving,"10 "[persuading] bargainers to move in a particular direction," "[replacing] the parties' provisional commitments with unconditional, formal commitments," ${ }^{12}$ and "[facilitating] a movement in the direction of conflict settlement."13

Based on laboratory research findings, different aspects of mediation have been found to have patterned effects on the manner in which concessions are made or agreements reached. For example, it is claimed that negative third party affiliation reduces disputants' outcome expectations and thereby improves the likelihood of an agreement. ${ }^{14}$ Another finding is that negotiators facing a binding third party decision behave

7. Saadia Touval, The Peace Brokers: $M e$ diators in the Arab-Israeli Conflict, 1948-1979 (Princeton, NJ: Princeton University Press, 1982), p. 326.

8. Roy J. Lewicki and Joseph A. Litterer, Negotiation (Homewood, IL: Richard D. Irwing, 1985), p. 299.

9. Jeffrey Z. Rubin and Bert R. Brown, The Social Psychology of Bargaining and Negotiation (New. York: Academic Press, 1975), p. 56.

10. Dean G. Pruitt, Negotiation Behavior (New York: Academic Press, 1981), p. 203.

11. Ibid.

12. Lars G. Stenelo, Mediation in International Relations (Sweden: Studenlitteratur, 1972), p. 108.

13. Jacob Bercovitch, Social Conflicts and Third Parties (Boulder, CO: Westview Press, 1984).

14. Donald E. Conlon and William Ross, "The Effects of Partisan Third Parties on Negotiation Behavior and Outcome Perceptions," Journal of Applied Psychology, 78(2):280-90 (1993). 
in a more conciliatory fashion and are more likely to reach an agreement than those facing a nonbinding decision. ${ }^{15}$ Parties who experience a high level of conflict intervention by a mediator are relieved from the sense of personal weakness that prevents them from making concessions. ${ }^{16}$ Another research project concluded that in cases where a mediator grants rewards, negotiator concessions are larger and joint outcomes are more valuable than in cases in which no rewards are involved. ${ }^{17}$ Finally, negotiators evaluated their behavior as relatively inflexible in situations where the mediator appeared at the end of the talks. ${ }^{18}$

A mediator can use different techniques and strategies to provide negotiating flexibility. In a continuum from passive to active roles, passive roles involve elements for providing a good communication environment for the participants. "Reflexive tactics," "reflective behavior,"

15. Dean G. Pruitt and Douglas F. Johnson, "Pre-Intervention Effects of Mediation versus Arbitration," Journal of Applied Psychology, 56:1-10 (1972).

16. Dean G. Pruitt and Douglas E. Johnson, "Mediation as an Aid to Face Saving in Negotiation," Journal of Social Psychology (1970).

17. James A. Wall, "The Effects of Mediator Rewards and Suggestions upon Negotiations," Journal of Personality and Social Psychology, 37:1554-60 (1979).

18. Daniel Druckman, "The Situational Levers of Negotiating Flexibility," Journal of Conflict Resolution, 37(2): 236-76 (1993).

19. K. Kressel and Dean G. Pruitt, "Themes in the Mediation of Social Conflict," Journal of Social Issues, 41:179-98 (1985); idem, eds., $M$ diation Research (San Francisco: Jossey-Bass, 1989).

20. Bercovitch, Social Conflicts and Third Parties. "mediator as communicator"21 are terms used in the literature to define passive roles. The mediator as a formulator ${ }^{22}$ identifies a relatively more active role than one of simply transmitting and interpreting messages. In this role, the mediator takes creative initiatives to facilitate a more productive process and to reduce situational complexities. Providing a neutral environment, deciding who will participate in the negotiations, controlling outside pressure, and ordering the issues are some of the activities of the formulator role. A mediator's communicator and formulator roles generally go hand in hand, and the combined effort is often called the facilitator role of the mediator.

More active roles consist of behaviors that modify the existing physical and social structure of negotiations or create new structures that enable the negotiators to reduce their inflexibility. The mediator as a manipulator ${ }^{23}$ involves a role that enables mediators to use their own resources to change the structure of the dispute and move the parties into an agreement. "The mediator as a manipulator requires leverage-resources of power, influence, and persuasion that can be brought to bear on the parties to move them to agreement."24

Based on the foregoing conceptual formulation, this article argues that mediators who have a high capacity

21. I. William Zartman and Saadia Touval, "International Mediation: Conflict Resolution and Power Politics," Journal of Social Issues, 41(2):27-45 (1985).

22. Ibid.

23. Ibid.

24. Saadia Touval and I. William Zartman, eds., International Mediation Theory and Practice (Boulder, CO: Westview Press, 1985), p. 12. 
to manipulate a conflict environment produce both flexibility and a sustainable agreement. Mediators whose manipulation capabilities are weak, on the other hand, are limited to producing flexibility. This article also argues that the particular stage at which manipulation occurs affects the outcome of negotiations. More specifically, the article shows that manipulation before the negotiation is more effective than manipulation during the negotiation. The empirical base for such arguments involves case studies of peace negotiations, including mediation efforts by the EU, the United Nations and EU together, and the United States regarding Bosnia-Herzegovina. ${ }^{25}$

\section{BACKGROUND}

The international recognition of Bosnia-Herzegovina as an independent sovereign state in early 1992 increased violence in the region. Since February 1992, peace initiatives have been launched, first by the EC mediators, Jose Cutiliero and Lord Carrington. After the resignation of Lord Carrington from the peace talks in August 1992, this attempt was replaced by a U.N.-EC initiative. Lord Owen, first with Cyrus Vance and then with Thorvald Stoltenberg, arranged different forums and plans for a peaceful settlement of the dispute. Despite temporary agreements in the London Peace Conference of August 1992 and the Geneva Ministerial

25. The author would like to thank to Yonca Gunduz, Burcu Akan, Yasemin Ersolak, and graduate students of the "Third Party Intervention" course at Bilkent University for their assistance in investigating the cases presented in this article.
Talks of December-January 1992-93, these attempts did not produce a sustainable final agreement between the parties. The United States, on the other hand, began to act as a mediator in early February 1994, and brokered an agreement between the Bosnian Croats and Muslims.

\section{THE EC MEDIATION}

Starting in February 1992, Jose Cutiliero, the EC's chief negotiator, and Lord Carrington, chair of the ECsponsored peace conference, mediated the conflict in Bosnia-Herzegovina. The EC peace plan was based on a division of Bosnia-Herzegovina into three autonomous units along ethnic lines. The territory of each unit would be based on a "national absolute or relative majority." The EC plan did not offer concrete proposals and did not provide details for a solution. The mediators' main objective was to bring the parties together in an attempt to clarify the main points of disagreement. In this context, the mediators mostly facilitated the process in order to move the parties to an agreement.

Cutiliero and Carrington also tried to play the role of manipulator. The mediators asked for the support of other U.N. members to reduce the resources of the aggressor side. The U.N. Security Council adopted an extensive trade embargo against Serbia and Montenegro. The EC tried to modify the structure of the talks by agreeing to cooperate with the North Atlantic Treaty Organization (NATO) to police the U.N. sanctions, using air and naval power. In addition, it applied pressure to the Serbs 
by suspending the CSCE membership of Yugoslavia and isolating it politically. Finally, the EC attempted to weaken the Serbian side by raising the issue of autonomous areas within the Federal Republic of Yugoslavia. These manipulative attempts were undertaken during the negotiations and had limited effect on the structure of the conflict. One minor change was that, as a result of economic sanctions, Belgrade called back its citizens fighting in Bosnia-Herzegovina and serving in the Yugoslav National Army (JNA). Not all JNA members obeyed the order, however, and half of the JNA weaponry was left with the Bosnian Serbs. Another minor change was the shift in Belgrade's priorities from achieving a greater Serbia to getting the sanctions lifted. ${ }^{26}$ But these changes were not enough to move the parties to agreement.

Moreover, the mediators did not always get the support they needed from the EC and CSCE. On 25 January 1992, Carrington criticized the EC for recognizing the former Yugoslav republics of Croatia and Slovenia and thereby "prolonging the road to peace in Yugoslavia., ${ }^{27}$ On 24 August, two days before the start of international talks on the Yugoslav republics, the Europeans appeared to be backing away from the policy of partitioning Bosnia-Herzegovina along ethnic lines. ${ }^{28}$ The United States strongly opposed the idea of

26. Lawrence Freedman, "Why the West Failed," Foreign Policy, 97:53-69 (Winter 1994).

27. "Carrington Cites EC's Actions on Yugoslavia," Belgrade TANJUG, 2050 GMT, 25 Jan. 1992, in Foreign Broadcast Information Service, Western Europe, 92-018, 28 Jan. 1992.

28. The New York Times, 25 August 1992. "cantonization" from the beginning of the EC peace efforts. As a result, Carrington, the EC mediator who for nearly a year tried to negotiate peace in the Balkans, resigned on $25 \mathrm{Au}$ gust 1992. This resignation was considered a signal that Europe, having failed to deal with this problem on its doorstep, had yielded authority to the United Nations.

\section{Flexible moves during the negotiations}

Although no agreement was signed at the end of EC mediation, there had been flexible moves by the parties as they sought a solution to the conflict. On 24 February 1992, in the second round of the European Community Peace Conference on Yugoslavia, the parties agreed that Bosnia-Herzegovina would remain within the existing borders. They also confirmed that future BosniaHerzegovina constitutional arrangements would be based on several entities and that talks would be resumed through EC mediation..$^{29}$ This was an agreement in principle on the division of Bosnia-Herzegovina along ethnic lines. For the Bosnian Muslims, this was a concession relative to their initial position advocating a united, independent Bosnia-Herzegovina.

Later, the mediators developed a more comprehensive plan incorporating Serb, Muslim, and Croat demands. The result was an agreement on the division of Bosnia-Herze-

29. "Bosnia-Herzegovina Officials Discuss Future," Belgrade TANJUG Domestic Service, 1755 GMT, 22 Feb. 1992, in Foreign Broadcast Information Service, Western Europe, 92-037, 25 Feb. 1992. 
govina along ethnic, economic, and functional lines..$^{30}$ On 18 March 1992, leaders of the three main ethnic groups signed the EC peace plan providing for Bosnia-Herzegovina's division into three autonomous units along ethnic lines. Later in the month, the Bosnian government moved away from these principles. President Alija Izetbegovic, explaining why he initially signed the plan, stated that he had been isolated and that the EC mediators had insisted on acceptance as a precondition for the diplomatic recognition of BosniaHerzegovina, his government's main short-term objective. ${ }^{31}$ In April, in an attempt to revitalize the peace process, the heads of the three nationalist parties signed a new cease-fire agreement and agreed to resume negotiations under EC sponsorship in Lisbon. However, on 2 May, the Lisbon negotiations failed when the cease-fire was breached.

Later in May, the U.N. Security Council identified Serbia as the principal aggressor in the Bosnian war and passed Resolution 757, which imposed an extensive trade embargo on Serbia and Montenegro. On 17 July 1992, the parties agreed to put heavy armaments under U.N. supervision, to begin a 14-day cease-fire, and to return to London on 27 July for indirect talks. ${ }^{32}$ In London in July, a modest agreement was reached to form a "committee in the field" to deal

30. British Broadcasting Corporation, Summary of World Broadcasts, 29 Feb. 1992, EE/1317.

31. "Yugoslavia Moves towards Bosnian Independence," Keesing's Record of World Events, pp. 38832-33 (Mar. 1992).

32. The New York Times, 18 July 1992. with human rights violations..$^{33}$ On 28 August, the London Peace Conference adjourned with an agreement by Serbian leaders to lift the siege of Sarajevo and other Bosnian cities, to close detention camps, and to turn over heavy arms to the United Nations. The parties also agreed on the establishment of six working groups to consider all aspects of the problem. ${ }^{34}$ The EC peace process ended with the resignation of Lord Carrington from the chairmanship of the process, and a new period of peace talks started under U.N. and EC auspices. Some flexible negotiating behavior by the parties had developed during this initiative, in spite of the failure to achieve a final settlement. The number of events and actions can be grouped into three categories of flexibility-bargaining concessions, problem-solving cooperation, and movement toward problem solvingas shown in Table 1.

\section{THE U.N.-EC MEDIATION: VANCE AND OWEN}

At the London Peace Conference of August 1992, on the initiative of the United Nations and the EC, a new forum for peace negotiations was formed, and the International Conference on Former Yugoslavia began its work as a permanent organization in Geneva. Two mediators, Cyrus Vance, representing the United Nations, and Lord David Owen, the EC's chief negotiator on the Balkans, were

33. Ibid., 30 July 1992.

34. British Broadcasting Corporation, Summary of World Broadcasts, 26 Aug. 1992, $\mathrm{EE} / 1467$. 
TABLE 1

FLEXIBLE BEHAVIORS DURING MEDIATION ATTEMPTS CONCERNING BOSNIA-HERZEGOVINA

\begin{tabular}{lccc}
\hline \hline & \multicolumn{3}{c}{ Flexible Behavior } \\
\cline { 2 - 4 } & $\begin{array}{c}\text { Bargaining } \\
\text { concessions }\end{array}$ & $\begin{array}{c}\text { Problem-solving } \\
\text { cooperation }\end{array}$ & $\begin{array}{c}\text { Movement toward } \\
\text { problem solving }\end{array}$ \\
\hline EC mediation & 6 & 2 & 2 \\
U.N.-EC (Vance-Owen) mediation & 4 & 9 & 4 \\
U.N.-EC (Owen-Stoltenberg) mediation & 4 & 6 & 1 \\
U.S. mediation & 1 & 3 & 0 \\
\hline
\end{tabular}

appointed to pursue the peacemaking activities. ${ }^{35}$

\section{Mediator tactics}

The Vance-Owen peace plan was the first attempt by outside mediators to find a middle ground between the Bosnian government's insistence on a unitary state and Croatian and Serbian ambitions to divide the republic into three ethnically based states. The peace plan envisioned dividing Bosnia-Herzegovina into 7 to 10 largely autonomous provinces under a loosely organized central government. The role of Vance and Owen, as mediators, was that of both facilitator and manipulator. In their facilitator role, they acted as communicators between the parties, since President Izetbegovic refused to hold face-to-face negotiations with the Bosnian Serb leaders. Their plan did not reflect the position of one party at the expense of others but tried to find a compromise solution. To narrow down the differences between the parties, they went over maps of BosniaHerzegovina, region by region, town by town, village by village, to deter-

35. The New York Times, 4 Sept. 1992. mine who would control autonomous regions of the future republic. ${ }^{36}$

In their manipulator role, the mediators tried to change the circumstances of the conflict by using their own resources. While the peace negotiations were proceeding, they urged the Security Council to tighten sanctions against Serbia and the former Yugoslav Republic. ${ }^{37}$ The threat to implement the U.S. "lift and strike"38 intervention plan was also used by the mediators to move parties toward an agreement. The United Nations promised the Bosnian Muslims to enforce a no-fly zone and issued an ultimatum to the Serbs to accept the Vance-Owen plan. NATO endorsed the U.N. Security Council's decision that banned all military flights over Bosnia. Vance and Owen also relied on political backing from the United States and Russia, asking the latter to press the Bosnian Serbs into accepting the plan. ${ }^{39}$ The mediators believed that the Clinton administration held the key to a peace settlement. Owen pre-

36. Ibid., 29 Dec. 1992.

37. Guardian, 14 Nov. 1992.

38. Lifting the arms embargo, to allow weapon supplies to Bosnian government forces, and striking against Serb positions.

39. Independent, 10 Feb. 1993. 
dicted that, provided the Americans came on board, the Muslims and the Serbs would accept the peace package under pressure from the Security Council. ${ }^{40}$

The negotiators failed to gain U.S. support for the plan, however. The U.S. administration appeared to withdraw from the West's common front, saying that the plan was unfair to Bosnian Muslims and that proposals to divide Bosnia into 10 autonomous provinces under a weak central government would lead to a gradual partition of the republic. ${ }^{41}$ Once again, manipulative tactics were not effective enough to change the structure of the conflict in a way that would lead the conflicting parties to a final agreement. The three warring parties in Bosnia were aware that the mediators had no political backing and that they had more than one master to please. ${ }^{42}$

\section{Flexible moves during the negotiations}

Although no formal agreement was achieved, several examples of flexible negotiation behavior occurred prior to and during the Geneva talks. Before the Geneva talks, the parties made a number of conciliatory gestures. On 12 September 1992, Vance announced that Croatia and federal Yugoslavia had agreed to reopen a major road between their capitals and to establish a demilita-

40. Guardian, 2 Feb. 1993.

41. Ibid., 3-4 Feb. 1993; Times (London), 6 Feb. 1993; Daily Telegraph, 6 Feb. 1993.

42. Economist, 26 Feb. 1994. rized zone in southern Croatia. ${ }^{43}$ On 14 September, all three factions in Bosnia-Herzegovina agreed on openended discussions to end the fighting, ${ }^{44}$ although on the first day of the Geneva talks, leaders of the three communities failed to meet. ${ }^{45}$ On the road to the second round of Geneva talks, the parties again made efforts to ameliorate the climate of negotiations. On 21 September, President Izetbegovic of Bosnia-Herzegovina outlined a peace plan to end the war. ${ }^{46}$ In October, Izetbegovic offered concessions, saying he would send a senior military officer to take part in talks on ending hostilities around his capital. ${ }^{47}$

However, during the period of 2430 October 1992, during the second round of the Geneva Conference, differences emerged between the Bosnian government and the delegation of Bosnia's Serbs and Croats. ${ }^{48}$ On 3 November, the Bosnian Serb parliament rejected the constitutional proposal offered by the mediators and withdrew its delegation from the talks. ${ }^{49}$ Later, the Bosnian Serb leader proposed to stop the fighting but only if the region was divided along the ethnic lines that the mediators had rejected. ${ }^{50}$

In the beginning of January 1993, the mediators presented proposals for

43. The New York Times, 12 Sept. 1992.

44. Ibid., 14 Sept. 1992.

45. Ibid., 22 Sept. 1992.

46. Ibid.

47. Ibid., 22 Oct. 1992.

48. British Broadcasting Corporation, Summary of World Broadcasts, EE/1515 (Oct. 1992).

49. Times (London), 4 Nov. 1992.

50. Guardian, 11 Nov. 1992. 
the solution to the war ${ }^{51}$ and brought the parties together for direct talks on the proposals in Geneva, but on 6 January, the talks recessed with no progress in two key areas: the VanceOwen map of a newly structured Bosnia, and the Serbians' insistence on having their own mini-state in Bosnia. ${ }^{52}$ On 11 January, Radovan Karadzic, leader of the Bosnian Serbs, dropped his demand for a state within a state, agreeing to the constitutional proposals on condition that they were approved by the Bosnian Serb parliament. Bosnian Muslim and Bosnian Croat delegations also accepted the constitutional principles. ${ }^{53}$ Eventually, the Bosnian Serb Assembly accepted the outlines of the peace plan. On 23 January 1993, talks resumed involving three issues: (1) details of a new map of Bosnia, (2) the constitutional arrangements, and (3) cease-fire agreements. All three parties then signed the constitutional principles. ${ }^{54}$

On 1-5 March 1993, all the parties concerned met in New York to negotiate the Vance-Owen plan, and various parties signed different aspects of an overall settlement, ${ }^{55}$ some obviously influenced by a U.N. promise to enforce the no-fly zone.$^{56}$ However, on 2 April, the Bosnian Serb Assembly

51. "Bosnia-Hercegovina, New Peace Proposals," Keesing's Record of World Events, pp. 39277-78 (Jan. 1993).

52. Guardian, 7 Jan. 1993.

53. "Bosnia-Hercegovina, New Peace Proposals," p. 39277.

54. Guardian, 24 Jan. 1993; "Bosnia-Hercegovina, New Peace Proposals," p. 39278.

55. British Broadcasting Corporation, Summary of World Broadcasts, 6 Mar. 1993, $\mathrm{EE} / 1630$.

56. Ibid., EE/1649. rejected the conditional acceptance of the Vance-Owen plan and withheld support from the peace process..$^{57} \mathrm{On}$ 19 May, the Bosnian Croats and Bosnian Muslims agreed to end hostilities and establish a joint interim government and to carry out the Vance-Owen peace plan. ${ }^{58}$ However, the Bosnian Serbs rejected the idea of a federation offered by the BosniaHerzegovina presidency. ${ }^{59}$

Thus the Vance-Owen mediation effort failed to produce a sustainable agreement, although it included several examples of flexible negotiating behavior (see Table 1).

\section{THE OWEN-STOLTENBERG MEDIATION}

The Owen and Stoltenberg mediation effort was based on a peace plan that proposed the establishment of a new Bosnia-Herzegovina comprising three ethnically based states with a federal or confederal constitution. The plan for a Union of United Bosnian Republics was a combination of the Serb-Croat initiative for a confederation and the platform of the Bosnian presidency advocating a federal state. ${ }^{60}$ As in the previous U.N.-EC initiative, the mediators sought to facilitate the resolution of the conflict by trying to find acceptable ways to remove obstacles to an agreement. During the process, they tried to develop new versions of peace proposals

57. British Broadcasting Corporation, Summary of World Broadcasts, 26 Apr. 1993, $\mathrm{EE} / 1672$.

58. The New York Times, 19 May 1993.

59. British Broadcasting Corporation, Summary of World Broadcasts, 14 July 1993, $\mathrm{EE} / \mathbf{1 7 4 0}$.

60. Ibid., 31 July 1993, EE/1755. 
that contained compromise positions between the parties.

After a stalemate in October 1993, the mediators modified their strategy and took more active measures, changing the structure of the negotiations while the peace process proceeded. One measure taken to manipulate the situation was to create a new forum for the peace talks, the International Conference on the War in Bosnia-Herzegovina. The conference was held in Geneva in November. This time, in addition to the conflicting parties and the mediators, foreign ministers of $12 \mathrm{EC}$ states and special envoys of the U.S. and Russian presidents were also present. Another manipulative strategy was to put pressure on Serbia to give 3-4 percent more territory to the Bosnian Muslims. In return, the EC offered to suspend the sanctions against former Yugoslavia gradually. Similarly, the Bosnians were threatened with a possible withdrawal of U.N. military forces on the ground. ${ }^{61}$

\section{Flexible moves during the negotiations}

In the beginning of the negotiations, the Bosnian Muslims rejected the division of Bosnia-Herzegovina along ethnic lines and proposed a federal solution, while the Bosnian Serbs and Croats advocated a confederal solution. Later negotiations focused on the peace plan offered by the mediators. ${ }^{62}$ The Bosnian Serbs ac-

61. “Bosnia-Hercegovina," Keesing's Record of World Events, 25 Nov. 1993, p. 39743.

62. According to the peace plan, Bosnian Muslims, who composed 44 percent of the prewar population of Bosnia-Herzegovina, would cepted the plan, while the Croats accepted it on condition that it was accepted by the other two parties. However, the (mainly Muslim) Bosnian Assembly introduced new conditions for the acceptance of the proposal. ${ }^{63}$ In September the negotiations broke down.

Subsequently, separate negotiations between the Bosnian Croats and Muslims and between the Bosnian Serbs and Muslims took place and agreements were reached on a ceasefire- to be in effect by 18 Septemberand on the closure of the detention camps. In addition, the parties agreed on the formation of a "loose union" of the three republics of BosniaHerzegovina two years after the agreement. The republics would later have referenda on whether to remain within that union or to join neighboring states. Territorial issues remained unsolved, however. The Bosnian Croats did not accept the Muslim demand for the town of Neum on the Adriatic coast. Bosnian Muslim demands for a further 4 percent of territory were also rejected by the other parties. As a result, negotiations collapsed in October. Thereafter, the other parties strongly reacted to the

be allocated 30 percent of the territory in four blocks of land, connected by corridors; Serbs, who make up 31 percent of the population but currently control over 70 percent of the territory, were to get 52.5 percent of the territory; Croats, 17 percent of the population, would get 17.5 percent of the territory.

63. The conditions of the Bosnian government were that (1) the mediators should return to the principles of the 1992 London Peace Conference, which rejected territorial conquest by either force or ethnic cleansing; (2) the map should embrace these same principles; and (3) there should be U.S. and NATO guarantees to enforce the deal. 
Muslims' conditional acceptance of the tripartite division, and both the Bosnian Croats and the Serbs declared that they would not make concessions that they had planned to make in September regarding territorial issues. On 1-3 November 1993, at the talks chaired by the International Conference on Former Yugoslavia, a three-step strategy was accepted. First, there would be discussion of a cease-fire; second, consideration of economic reconstruction; and, finally, discussion of political questions. ${ }^{64} \mathrm{On}$ 18 November, an accord to guarantee safe passage for U.N. convoys was signed in Geneva by the parties.

A further stage of the peace negotiations began on 29 November, with the establishment of an International Conference on the War in Bosnia-Herzegovina. There, Bosnian Muslims declared that humanitarian issues and territorial access to the sea were of primary importance. The main change in their demands was their insistence on U.S. and NATO guarantees and on their obtaining 33.3 percent of Bosnia-Herzegovina territory. They also asked for sanctions against Croatia under NATO guarantees and for Sarajevo to be under U.N. control the first two years of any settlement. The Bosnian Serbs demanded the lifting of the sanctions and the division of Sarajevo into two cities.

On 23 December, the Serbs and Croats reached an agreement on concessions to the Bosnian Muslims, giving 33.3 percent of the territory to the Bosnian Muslims, provided that the Bosnian Croats received 17.5 per-

64. Report of the U.N. Secretary-General, S/26828, 1 Dec. 1993. cent. ${ }^{65}$ At the end of the negotiations, the Bosnian government accepted six of the seven demands, ${ }^{66}$ but they insisted on having access to the sea through Neum. The Bosnian Serbs rejected two of the demands, concerning the administration of Sarajevo and the opening of the Tuzla airport, while the Bosnian Croats accepted all conditions. ${ }^{67}$ On 19 January 1994 , an agreement between the Serbs and Croats was signed to open official representation offices in each other's capital. ${ }^{68}$

Regardless of this agreement, little actual progress was achieved on the major problems. A month later, in the new round of Geneva talks, the stalemate continued on vital issues, and the whole process was interrupted by the Serbian bombing of the marketplace in Sarajevo. The parties did, however, demonstrate some flexible negotiating behaviors during this process (see Table 1).

\section{THE U.S. INITIATIVE}

The U.S. decision to take an active stand to resolve the conflict in Bosnia-

65. British Broadcasting Corporation, Summary of World Broadcasts, 23 Dec. 1993.

66. The seven demands that formed the basis of a peace agreement were (1) agreement on a cease-fire, (2) secure, safe, and free passage of aid, (3) agreement of all parties to the partitioning of Bosnia-Herzegovina as previously decided, (4) acceptance of U.N. administration in Sarajevo, (5) acceptance of U.N. administration in Mostar, (6) the opening of the Tuzla airport, and (7) acceptance by the three parties of the decision on access to the sea near Neum.

67. British Broadcasting Corporation, Summary of World Broadcasts, 29 Dec. 1993.

68. International Herald Tribune, 19 Jan. 1994. 
Herzegovina was after the market shelling in Sarajevo in February 1994. Other than one facilitation instance by the special U.S. envoyCharles Redman's discussion with the Muslim Bosnian leader, on 14 February, to determine the government's bottom line for an acceptable peace settlement-the role of the United States in mediating the Bosnian conflict was mainly that of a manipulator. A major difference, however, was that the United States manipulated the conflict environment before getting parties to the negotiating table. It did this by modifying the existing physical and social structure of the negotiations and by creating new structures that provided the parties with enough negotiating flexibility to reach an agreement.

\section{Modifying the existing structure and creating new structures}

After the market shelling, the United States took three concrete steps to change the dynamics of the conflict and of attempts to resolve it. The first step was to provide leadership in brokering the 10-day NATO ultimatum. The second action was the reestablishment of the credibility of Allied threats. The U.S. government gave a constant "fly and die" message to the Bosnian Serbs. On 17 February, President Clinton declared that the "Allies are dead serious" about air strikes. In the meantime, the U.S. diplomatic corps in Serbia was told to leave the country, again, as a signal of firmness.

The third concrete action was the shooting down of four Serb military aircraft over Bosnia on 28 February by American fighters, an action the Russians said they did not object to. This brought an end to the long-lasting stalemate and signaled, for the first time in the history of the conflict, the determination of the world's only superpower to use its influence in Bosnia. It was also the end of the Geneva peace process chaired by Owen and Stoltenberg. The EU and the United Nations lost the initiative over the talks, which were thereafter held in Washington and Moscow. ${ }^{69}$

The United States was also able to bring additional resources to the negotiations. First, Russia was brought directly into the process, and the two countries increased the likelihood of the parties' involvement in the peace process by playing a "good guy-bad guy" routine with the various conflicting factions.

Second, the United States shifted its weight and played with the bargaining powers of the parties. By emphasizing minimum commonalities-"you are the victims of a common enemy"-the United States was able to broker a coalition between the Bosnian Croats and Muslims, leaving the Bosnian Serbs relatively weak in the process and isolating them as the main villain.

Third, by using carrots and sticks, the U.S. government told Bosnians that they had to negotiate and not expect to recover any territory through the use of force. The Croatian government was warned that it would face sanctions if it continued to support the Bosnian Croats. ${ }^{70}$ Posi-

69. Economist, 5 Mar. 1994.

70. International Herald Tribune, 3 Mar. 1994. 
tive incentives included being offered limited membership in the EU; taking part in NATO's Partnership for Peace program; and having access to the resources of international financial institutions, such as the International Monetary Fund and the World Bank.

\section{Flexible moves during the negotiations}

The U.S.-backed plan promised at least 33.3 percent of the country to the Bosnian Muslims and $\mathbf{1 7 . 5}$ percent to the Croats, giving each an ethnic-majority area. Together, this would give them 50.8 percent of Bosnia-Herzegovina, leaving the Serbs with the rest. On 2 March 1994, Bosnian Muslim and Croat representatives signed a detailed political and military document for a federation. ${ }^{71}$ On $18 \mathrm{March}$, a formal agreement between the Croats and Muslims was signed. ${ }^{72}$ Later in March, Muslim and Croat assemblies approved the constitution of the federation. ${ }^{73}$

In the end, the parties agreed to the establishment of a federation between the Bosnian Croats and the Muslims, and a loose confederation between this federation and Croatia. One settlement had been achieved and some flexibility was demonstrated, as shown in Table 1.

\section{CONCLUSION}

Analysis of the four mediation initiatives shows that flexible negotiating behavior occurred in all of them,

71. Ibid.

72. Ibid., 19-20 Mar. 1994.

73. Ibid., 1 Apr. 1994. irrespective of whether a sustainable agreement was achieved. Negotiating flexibility manifested itself in the form of concession making, agreements on rules and procedures, agreements on mutual solutions, and introduction of new proposals. In other words, it consisted of conciliatory elements of positional bargaining, cooperative elements of problem-solving negotiations, and activities to convert positional bargaining to problem solving.

The analysis did not, of course, provide any evidence regarding the intentions behind flexible negotiating behavior. The reasons for flexible behavior may vary from a willingness to end a conflict to strategic concerns, such as assisting a military buildup, creating a positive public image, or establishing a coalition to isolate another party. However, the analysis supports the literature regarding the effects of a mediator on flexible negotiating behavior. Moreover, regardless of the final result of the mediation attempts, all the intermediaries helped the parties to engage in flexible behavior, thus facilitating a movement in the direction of conflict settlement.

In all four cases, the mediators also acted as manipulators, trying to use their own resources, power, influence, and persuasion to change the structure of the dispute and move the parties toward an agreement. The difference between the U.S. and other mediation attempts cannot thus be explained simply by whether leverage was used or not, but by the extent of the leverage and when it was used. One significant difference between the U.S. and other mediation efforts was that the EC and U.N.-EC media- 
tors started their activities by offering a peace plan to the parties. The first three sets of mediators undertook negotiations with their text as the basis of the talks. The mediators then used manipulative tactics en route to generating a mutually acceptable text by taking measures to change the structure of the conflictby cooperating with NATO to police U.N. sanctions or by asking the outsiders to put pressure on the parties. The United States, on the other hand, first acted as a manipulator, changing the structure of the conflict, and then brought the parties together to negotiate a text. While the first version of using leverage contains considerable uncertainty in terms of the actual implementation and possible effects of that manipulation, in the second, the structural change is concrete, certain, and, thus, more credible. Simple timing is not the only explanation for the differences between the two manipulative strategies.

The extent to which leverage was used by the mediator to bring about major change in the structure of the dispute also appeared to be a factor in whether the negotiations yielded concrete results. Apparently, the use of force, as in the U.S. case, and imposing a trade embargo, as in the U.N.-EC cases, had significantly different impacts on the outcome of the mediation.

\section{AFTERWORD}

Conflict over Bosnia-Herzegovina continues despite mediation attempts by outsiders. In addition to the characteristics of the negotiation and mediation efforts mentioned ear- lier in this article, those of the larger international environment in which such efforts have taken place have had a major impact on the failure to find a sustainable peace. In the postCold War era, the Bosnian conflict has become an indirect forum in which to negotiate the future rules of conduct between Western powers. Each decision regarding Bosnia-Herzegovina has implications for the dynamics of the post-Cold War U.S.European relationship, on the future and credibility of European security systems (particularly NATO), and on the fragile balances between members of the EU.

Another feature of this new international environment is the ambiguous relationship between the Western powers and Russia. The West clearly made a conscious effort to treat Russia as a partner and not as a party to the conflict in former Yugoslavia. However, the West's sensitivity to Russia's internal political developments, such as increasing nationalist movements, provided Russia with the freedom to play a role as both a party and a partner in the conflict, putting significant constraints on collective decision-making mechanisms set up to develop and implement a peaceful solution.

The final feature was the interblocking rather than interlocking character of the conflict resolution mechanisms of existing international institutions. The fruitless interplay between the United Nations and NATO in sharing responsibilities and synchronizing intervention attempts is an example of this interblocking. In summary, besides differences in the performances of the four sets of me- 
diators, failure to produce a viable lateral and bilateral negotiations of solution to the conflict in Bosnia- the outsiders involved in working out Herzegovina was and is closely re- an undeclared agenda.

lated to unproductive sets of multi- 